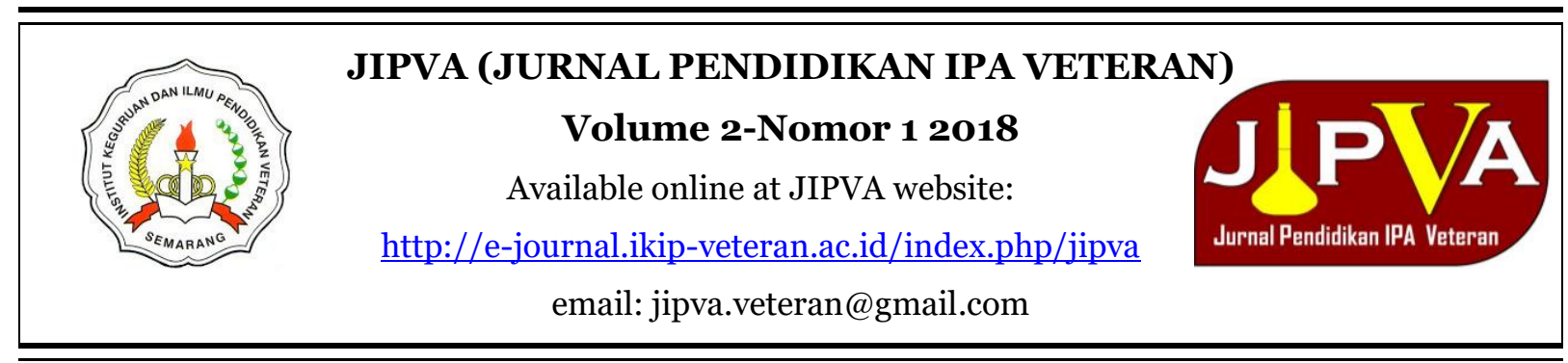

\title{
PENERAPAN PEMBELAJARAN IPA TERINTEGRASI UNTUK MEMETAKAN NILAI IMAN (BUDI PEKERTI) PESERTA DIDIK SEKOLAH DASAR
}

Naomi Dias Laksita Dewi

Unika Atma Jaya Jakarta

email: naomi.dias@atmajaya.ac.id

\begin{abstract}
Abstrak
Tujuan penelitian ini yaitu untuk mengetahui penerapan pembelajaran IPA terintegrasi nilai iman budi pekerti di sekolah dasar dan memetakan refleksi nilai iman peserta didik. Metode penelitian yang digunakan berupa desktiptif kualitatif. Instrumen yang digunakan yaitu pedoman Focus Group Discussion (FGD), lembar observasi keterlaksanaan pembelajaran terintegrasi dan hasil refleksi peserta didik. Hasil penelitian menunjukkan bahwa 1) Pembelajaran IPA terintegrasi nilai iman budi pekeri dapat diimplemantasikan di sekolah dasar kelas IV. Hasil implementasi menunjukkan bahwa pembelajaran SCL terintegrasi berada dalam kategori tinggi dengan nilai $77,78 \%$ meningkat $33,33 \%$ dari kegiatan pembelajaran awal. 2) Hasil refleksi materi peserta didik menunjukkan 83,72\% peserta didik berada di atas kriteria ketuntasan minimal. Pembelajaran IPA terintegrasi juga mampu mengantarkan peserta didik untuk merefleksi nilai iman budi pekerti dengan baik. Hal ini terlihat dari setiap jawaban yang dituliskan memuat sikap diri, mengetahui progres pengalaman, manfaat dan rasa syukur kepada Tuhan dengan berbagai sikap.
\end{abstract}

Kata kunci: pembelajaran terintegrasi, pembelajaran IPA, nilai iman, budi pekerti

\section{IMPLEMENTATION OF INTEGRATED SCIENCE LEARNING TO MAP THE FAITH VALUES (CHARACTERS) OF ELEMENTARY SCHOOL STUDENTS}

\begin{abstract}
The aims of this study is to determine the application of integrated science learning and faith values in primary school and map the reflection of faith values of learners. The research method used is qualitative desctiptive. The instrument used is the guidance of focus group discussion (FGD), observation sheet of the implementation of integrated learning and the reflection result of learners. The result of the research shows that 1) Integrated learning of science can be implemented in elementary school class IV. The results of the implementation indicate that the integrated SCL learning is in the high category with the value of 68,75\%, it's increase 37,50\% from the initial learning activity. 2) The result of the reflection of the learner's material shows that $83.72 \%$ of learners are above the minimum mastery criteria. Integrated science learning is also capable of delivering learners to reflect the values of good character faith. This can be seen from each written answer containing the attitude of self, knowing the progress of experience, benefits and gratitude to God with various attitudes.
\end{abstract}

Keywords: integrated learning, science learning, faith values, characters 


\section{PENDAHULUAN}

Perkembangan ilmu pengetahuan dan teknologi yang semakin pesat serta sulit diantisipasi memberi pengaruh besar terhadap model pembelajaran peserta didik dari tingkat pendidikan dasar sampai di pendidikan tinggi. Sementara itu, liberalisasi ekonomi juga turut mempengaruhi peningkatan tuntutan mutu sumber daya manusia yang berkompeten dan siap memasuki era global. Hal ini menyebabkan kebutuhan akan pengetahuan dan keterampilan yang dimiliki seorang pendidik juga semakin meningkat. Oleh karena itu, kualitas sumber daya manusia dengan penguasaan pengetahuan dan keterampilan yang memadai sudah seharusnya dipersiapkan sejak dari pendidikan dasar. Pengembangan pendidikan karakter yang mampu membentuk sikap makin diperlukan demi menyikapi tuntutan kebutuhan sumber daya alam yang berkualitas.

Cara belajar peserta didik yang banyak terfokus pada pemberian bahan pelajaran atau penyampaian informasi oleh pengajar (knowledge transfer), menghafal teks pelajaran (text book oriented), orientasi pada hasil atau nilai angka sudah waktunya berubah ke arah proses pembelajaran yang lebih melibatkan peserta didik sebagai subyek. Dalam mempersiapkan generasi muda menjadi generasi yang berkualitas, peserta didik saat ini perlu mengalami dan menerapkan proses pembelajaran aktif. Fokus pembelajaran aktif terletak pada pengembangan kompetensi pengetahuan dan keterampilan yang mendorong pemikiran analitis dan kritis dari peserta didik. Pendekatan belajar aktif kita kenal dengan sebutan Student Centered Learning (SCL).

Melalui pengalaman belajar yang diperoleh peserta didik akan mampu menumbuhkan sikap pribadi yang lebih mandiri dan terampil mengolah kehidupannya secara bertanggung jawab. SCL mendorong peserta didik menjadi pelaku aktif dalam kegiatan belajar. Namun pengertian SCL bukanlah sekedar mendorong peserta didik melakukan suatu kegiatan tertentu, sementara pendidik bersikap pasif. Justru pendekatan SCL menuntut seorang pendidik turut aktif dalam proses pembelajaran bersama-sama dengan peserta didik. Seorang pendidik bertugas memfasilitasi peserta didik dalam melakukan eksplorasi bahan-bahan belajar, mendiskusikan berbagai informasi yang diperoleh terkait dengan tema pembelajaran untuk kemudian diolah bersama peserta didik sehingga melalui proses tersebut, peserta didik mampu menghasilkan gagasan-gagasan yang dapat dipertanggungjawabkan.

Pembelajaran di kurikulum 2013 mementingkan kompetensi peserta didik. Kompetensi ini dituliskan di dalam kompetensi dasar, diturunkan menjadi indikator pembelajaran dan dilaksanakan dengan tujuan pembelajaran. Kompetensi peserta didik mencakup kompetensi sikap (spiritual dan sosial), kompetensi pengetahuan dan kompetensi keterampilan. Idealnya, ketiga kompetensi tersebut sebaiknya dapat terlaksana dengan seimbang. Berdasarkan implementasi kurikulum 2013 ini diharapkan di dalam kompetensi spiritualnya dapat menghargai dan menghayati ajaran agama yang dianut. Pada kompetensi sosial diharapkan mampu menghargai dan menghayati perilaku jujur, disiplin, tanggung jawab, peduli dalam berinteraksi dengan lingkungan sosialnya. Di kompetensi pengetahuan mengharapkan peserta didik mempunyai pengetahuan berdasarkan rasa ingin tahunya tentang ilmu pengetahuan, teknologi, seni dan budaya terkait fenomena alam. Sementara, pada 
kompetensi keterampilan peserta didik diharapkan mampu mencoba, mengolah, menyajikan dalam ranah konkret (menggunakan, mengurai, merangkai, memodifikasi dan membuat) dan ranah abstrak (menulis, membaca, menghitung, menggambar dan mengarang).

Melihat implementasi kurikulum 2013 di lapangan, masih banyak terlihat nilai pendidikan khususnya kompetensi spiritual belum diintegrasikan secara tepat. Kompetensi spiritual dibelajarkan di pembelajaran agama dalam porsi terbesar selain kewarganegaraan. Apabila kita mengacu pada kurikulum 2013 diharapkan kompetensi-kompetensi ini dapat dicapai dalam setiap pembelajaran, termasuk di dalam pembelajaran IPA. Pembelajaran IPA juga bisa menyumbang pendidikan nilai melalui bentuk pendidikan sikap ilmiah dan kerja ilmiah yang merupakan bagian metode ilmiah. Kompetensi spiritual yang hanya dipelajarkan di pelajaran agama membangun pengertian bahwa pendalaman iman hanya bisa diajarkan di pelajaran agama. Pendidikan nilai yang saat ini sedang digalakkan tidak berdiri sendiri sebagai mata pelajaran, tetapi harus dipadukan dengan materi pendukung kompetensi dasar yang sesuai (Salirawati, 2011).

Hasil Focus Group Discusion (FGD) dan observasi kelas di kelas IV A, B dan C SD Santa Maria Juanda menunjukkan bahwa meski pembelajaran sudah berpayung tematik namun pelaksanaaanya masih terpisah. Hampir sebagian besar penyampaian pembelajaran senang disampaikan melalui pemaparan pendidik yang minim dilakukan demonstrasi khususnya di pembelajaran IPA. Diskusi kelompok sudah dilakukan di beberapa mata pelajaran misalnya bahasa Indonesia dan kewarganegaraan. Mata pelajaran agama dilaksanakan sendiri pada jam khusus Pendidikan Agama. Pelajaran Agama tidak dilaksanakan secara tematik dengan mata pelajaran lain meski pendidik sebenarnya sudah menyadari bahwa sebaiknya mata pelajran agama juga dilaksanakan secara tematik antar mata pelajaran.

Pengamatan di lapangan, pendidik menggunakan bahan ajar yang sama seperti sekolah dasar negeri sehingga belum menampilkan ciri khas nilai-nilai spiritual (Kristen Katolik) itu sendiri. Kandungan agama kristiani juga belum banyak ditemukan baik di pembelajaran dan bahan ajar mata pelajaran IPA. Beberapa siswa menganggap IPA sebagai pelajaran yang sulit, kurang menyenangkan, dan ketertarikan terhadap IPA masih kurang. Peneltian Akpinar, Yildiz, Tatar, \& Ergin (2009: 2807) menyebutkan bahwa ada perbedaan yang signifikan antara siswa lakilaki dan siswa perempuan terhadap ketertarikan IPA. Indikator sikap yang digunakan meliputi ketertarikan, kesenangan, pentingnya IPA, perlengkapan IPA, sikap terhadap pendidik IPA, IPA di masa depan, IPA di luar sekolah, sifat IPA dan nilai IPA. Jelen \& Lockett (2014: 6) melakukan penelitian untuk mengetahui hubungan antara sikap religius, keberpihakan dan kebijakan sikap terhadap IPA. Hasilnya menunjukkan variabel religius (pandangan keagamaan dan kitab suci) berhubungan erat dan signifikan terhadap sikap terhadap IPA.

Pembagian plot mata pelajaran IPA dan IPS diampu oleh seorang pendidik, Matematika dan PKn oleh satu orang pendidik, Bahasa Indonesia dan KTK juga oleh seorang pendidik. Pendidik masih bertindak layaknya seorang pendidik bidang 
studi, dengan alasan supaya lebih fokus melakukan pendalaman materi, apabila dilakukan dengan tematik hanya mengena ke lapis-lapis materi saja. Melakukan diskusi masih menjadi hal yang belum dipahami optimal oleh siswa kelas IV. Kosa kata perintah menjadi kendala apabila dilakukan diskusi kelompok. SCL dipahami sebagai pembelajaran yang aktif, anak menemukan sendiri informasi. Pendidik merasa kewalahan jika semua materi menunut untuk dilakukan secara inkuiri ataupun diskoveri. Kendala fasilitas juga dirasakan oleh pendidik.

Kegiatan reflektif sudah pernah dilaksanakan beberapa kali tetapi tidak dilanjutkan. Kendala yang dihadapi adalah siswa tidak begitu tertarik menuliskan refleksi kegiatannya. Setiap akan memulai refleksi anak selalu bertanya "Berapa kalimat Bu/Pak?". Hal ini menjadi pertanyaan tersendiri bagaimana sebaiknya merencanakan kegiatan reflektif di akhir pembelajaran. Kegiatan refleksi yang sering dilakukan adalah refleksi terkait materi pelajarannya. Refleksi materi lebih menekankan kepada latihan soal dan pengayaan. Kegiatan refleksi tidak secara khusus menggali afektif anak untuk mengaitkan materi pelajaran dengan nilainilai spiritualitas yang bisa dihubungkan.

Pembelajaran yang baik wajib disusun oleh setiap pendidik. Pembelajaran disiapkan supaya siswa atau anak memiliki kecakapan-kecakapan yang bisa mereka lakukan di masa depan. Setidaknya terdapat empat kecakapan yang harus dimiliki oleh generasi abad 21 yaitu ways of thinking, ways of working, tools for working dan skills for living in the world (P21 Partnership for $21^{\text {st }}$ Century Learning). Siswa akan memiliki kecakapan-kecakapan tersebut apabila pendidik mampu mengembangkan pembelajaran dengan aktivitas kegiatan yang menantang siswa untuk berfikir memecahkan masalah. Pembelajaran yang disusun lebih baik diharapkan membekali peserta didik untuk bersiap menghadapi masa depan.

Dalam upaya meningkatkan kualitas pembelajaran di sekolah dasar, penelitian ini berupaya menerapkan pembelajaran IPA terintegrasi nilai keimanan atau budi pekerti. Dengan menciptakan pembelajaran terintegrasi ini diharapkan peserta didik dapat mengalami proses pembelajaran reflektif yang mampu memunculkan nilai keimanan melalui pembelajaran IPA

\section{METODE}

\section{Jenis Penelitian}

Pendekatan deskriptif kualitatif merupakan pendekatan yang dipilih dalam penelitian ini untuk mendiskripsikan hasil pemetaan nilai iman budi pekerti peserta didik SD di dalam pembelajaran IPA terintegrasi.

\section{Waktu dan Tempat Penelitian}

Target penelitian ini yaitu sekolah dasar di Jakarta yang sedang melaksanakan kurikulum 2013 dan memiliki kekhasan nilai iman budi pekerti.

\section{Target/Subjek Penelitian}

Subjek dalam penelitian ini yaitu 90 peserta didik kelas IV A, B dan C. Sekolah tersebut dipilih lokasi pertimbangan ada tidaknya proses pengintegrasian mata pelajaran.

\section{Prosedur}

Prosedur penelitian ini dilakukan melalui lima tahapan yaitu analisa, desain, pengembangan, implementasi, dan evaluasi refleksi. Sekolah sebagai lokasi penelitian dipilih berdasarkan lokasi dan ada tidaknya proses pengintegrasian mata pelajaran. Penelitian difokuskan pada pembelajaran IPA materi peduli terhadap lingkungan. 
Tahap desain menghasilkan lembar observasi, pedoman diskusi, rencana pelaksanaan pembelajaran dan penilaian. Pembelajaran dilaksanakan dengan mengoptimalkan fasilitas yang dipunyai sekolah dengan harapan pembelajaran menjadi lebih bermakna dan lebih memberikan pengalaman kepada peserta didik. Peneliti mengemas materi ini dengan tema "Aku dan Tumbuhan". Lembar observasi digunakan untuk mengamati pembelajaran IPA di kelas IV A, B dan C. Tujuannya untuk mengetahui dan mengambil "potret" pembelajaran yang sudah dilakukan selama ini. Peneliti melakukan $F G D$ dengan tiga orang pendidik kela IV guna menggali informasi pembelajaran. Rencana pembelajaran yang dibuat peneliti juga didiskusikan guna mendapat masukan dari pendidik.
Tahap pengembangan merupakan tahap pemantapan aktivitas pembelajaran tema "Aku dan Tumbuhan" dan pembuatan media pendukung. Di tahap ini, peneliti berdiskusi dengan pendidik pengampu mata pelajaran IPA dan Agama. Tahap selanjutnya adalah implementasi yaitu menerapkan rencana pelaksanaan pembelajaran di kelas IV A, B dan C. Peneliti dan pendidik saling berkolaborasi menciptakan kondisi kelas yang baik untuk melakukan pembelajaran terintegrasi. Di akhir kegiatan pembelajaran dilakukan refleksi baik secara materi dan korelasi dengan nilai iman budi pekerti seperti yang menjadi tujuan dalam penelitian ini. Diagram prosedur penelitian ini disajikan secara ringkas dalam Gambar 1 .

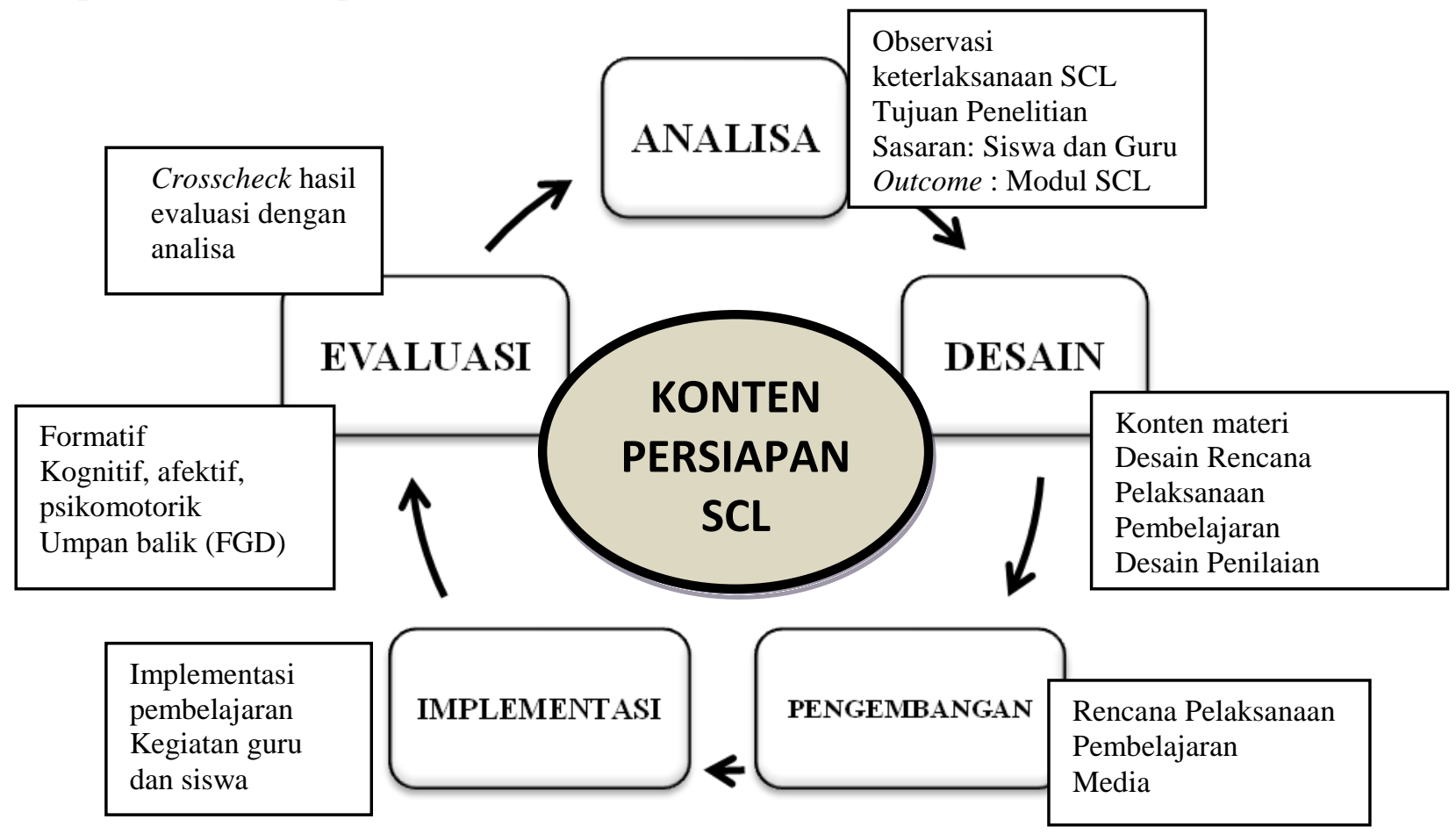

Gambar 1. Diagram Prosedur Penelitian 


\section{Data, Intrumen, dan Teknik Pengumpulan Data}

Data kualitatif diperoleh dalam penelitian ini. Dilakukan proses triangulasi untuk menguji data yang peneliti peroleh. Instrumen yang digunakan yaitu pedoman forum group discussion (FGD), lembar observasi keterlaksanaan pembelajaran terintegrasi dan hasil refleksi peserta didik.

FGD difokuskan kepada pembelajaran sekolah dasar terintegrasi dan dilakukan kepada tiga pendidik kelas IV SD Santa Maria Juanda. Pedoman FGD berisi daftar pertanyaan terbuka sehingga pendidik juga diperbolehkan untuk memberikan ide pendapat. Kegiatan observasi dilakukan untuk mengetahui dan mengambil "potret" pembelajaran. Hasil temuan observasi dan hasil FGD digunakan di tahap pengembangan rencana pelaksanaan pembelajaran.

\section{HASIL DAN PEMBAHASAN}

Penelitian ini bertujuan untuk memetakan nilai iman budi pekerti yang muncul di dalam pembelajaran IPA terintegrasi. FGD memperoleh informasi dari ketiga pendidik. Pedoman yang peneliti gunakan terangkum dalam Tabel 1. Pertanyaan yang digunakan peneliti bersifat terbuka sehingga pendidik dapat berurun rembug memberikan saran pendapat. $F G D$ direkam oleh peneliti agar tidak terdapat informasi yang terlewat.

\section{Tabel 1.}

Butir Pertanyaan Forum Group Discussion dari Pendidik

\begin{tabular}{|c|c|}
\hline Fokus FGD & Informasi \\
\hline $\begin{array}{l}\text { 1. Sekolah menggunakan kurikulum } \\
\text { apa? }\end{array}$ & Kurikulum 2013 \\
\hline $\begin{array}{l}\text { 2. Metode seperti apa yang sering } \\
\text { digunakan dalam pembelajaran? }\end{array}$ & $\begin{array}{l}\text { Senang dengan metode ceramah, demonstrasi sudah pernah dilaksanakan namun } \\
\text { belum banyak. Diskusi kelompok juga sudah dikenalkan. }\end{array}$ \\
\hline $\begin{array}{l}\text { 3. Apakah menyusun pembelajaran } \\
\text { secara terpadu atau tematik? }\end{array}$ & $\begin{array}{l}\text { Pembelajan disusun sendiri-sendiri dalam lingkup tim mengajar. IPA dan IPS } \\
\text { diampu pendidik A, MTK dan PKN diampu pendidik B, BI dan KTK diampu } \\
\text { pendidik C. }\end{array}$ \\
\hline 4. Tematiknya seperti apa? & $\begin{array}{l}\text { Belum disusun secara tematik menyeluruh. Matematika dilaksanakan di luar tema. } \\
\text { Pelajaran agama belum masuk dalam tematik. }\end{array}$ \\
\hline $\begin{array}{l}\text { 5. Bagaimana } \\
\text { pembelajarannya? }\end{array}$ & $\begin{array}{l}\text { RPP disusun oleh masing-masing pendidik. Ketiga pendidik mengembangkan RPP } \\
\text { dalam lingkup tema, pendalaman materi dilakukan masing-masing pendidik sesuai } \\
\text { dengan mata pelajaran yang diajar. Kurikulum } 2013 \text { menjadi pembatas pendalaman } \\
\text { materi dalam pendidik mengembangan materi ajar. Penilaian dilaksanakan dalam } \\
\text { tema. Soal terdiri dari beberapa mata pelajaran. Penilaian dipisah, dikembalikan ke } \\
\text { nilai masing-masing mata pelajaran menyesuaiakan kompetensi dasar. }\end{array}$ \\
\hline $\begin{array}{l}\text { 6. Bagaimana respon peserta didik } \\
\text { selama mengikuti pembelajaran? }\end{array}$ & Peserta didik mendapat hasil belajar kognitif yang baik \\
\hline $\begin{array}{l}\text { 7. Kendala yang dihadapi dalam } \\
\text { pembelajaran? }\end{array}$ & $\begin{array}{l}\text { Pembelajaran tidak mengcover semua mapel apabila pendidik memegang satu } \\
\text { kelas penuh. Pendidik merasa tidak menguasai semua mata pelajaran. Waktu } \\
\text { pembelajaran yang dirasa belum optimal. }\end{array}$ \\
\hline $\begin{array}{l}\text { 8. Bagaimana mengatasi kendala yang } \\
\text { dihadapi? }\end{array}$ & Pembagian mata pelajaran di masing-masing pendidik. \\
\hline $\begin{array}{l}\text { 9. Apakah Bapak/Ibu sudah pernah } \\
\text { mendengar mengenai } \\
\text { Centered Learning (SCL)? }\end{array}$ & $\begin{array}{l}\text { Pendidik sudah tahu bahwa pembelajaran aktif yang berpusat pada peserta didik. } \\
\text { Pembelajaran dengan pusat di peserta didik dilaksanakan tergantung dari materi } \\
\text { pelajaran }\end{array}$ \\
\hline $\begin{array}{l}\text { 10. Apa yang Bapak/Ibu ketahui tentang } \\
\text { SCL? }\end{array}$ & \\
\hline $\begin{array}{l}\text { 11. Apakah SCL sudah Bapak/Ibu } \\
\text { terapkan di dalam pembelajaran? }\end{array}$ & \\
\hline $\begin{array}{l}\text { 12. Bagaimana SCL yang Bapak/Ibu } \\
\text { lakukan? }\end{array}$ & \\
\hline $\begin{array}{l}\text { 13. Di dalam pembelajaran, bagaimana } \\
\text { nilai karakter atau pendalaman iman } \\
\text { dimunculkan? }\end{array}$ & $\begin{array}{l}\text { Belum dimunculkan di pembelajaran. Biasanya kegiatan refleski dilakukan dengan } \\
\text { peserta didik menuliskan dalam sebuah buku refleksi. Hanya saja kegiatan refleksi } \\
\text { hanya dilakukan pada jam wali kelas saja, belum di mata pelajaran. }\end{array}$ \\
\hline
\end{tabular}


Peneliti melakukan observasi di tiga kelas paralel yaitu IV A, IV B dan IV C. Di dalam melaksanakan kegiatan observasi peneliti berfokus pada dinamika kegiatan belajar mengajar, metode pembelajaran, media pembelajaran dan penilaian pembelajaran. Keempat aspek ini merupakan aspek Student Centered Learning (SCL) yang kemudian difokuskan lagi menjadi beberapa indikator. Indikatorindikator yang tercantum pada Tabel 2 menjadi pedoman peneliti untuk mengamati keterlaksanaan pembelajaran. Hasil pengamatan di pembelajaran awal menunjukkan bahwa keterlaksanaan SCL masih 33,33\% dari keempat aspek. Artinya, pembelajaran belum sepenuhnya dirancang dengan tujuan lebih mengaktifkan peserta didik dan memberikan pengalaman ke peserta didik. Keterlaksanaan pembelajaran termasuk dalam kategori rendah. Hal ini dimungkinkan karena pembelajaran belum menyajikan percobaan, demonstrasi dan kegiatan di luar kelas. Peserta didik masih banyak menghabiskan kegiatan pembelajaran dengan berlatih soal dan mendengarkan. Peserta didik sudah melakukan diskusi kelompok. Kemudian, indikator-indikator tersebut juga digunakan sebagai tolak ukur apakah pembelajaran yang peneliti rancang sudah memenuhi aspek SCL. Hasil pelaksanaan pembelajaran selama menerapkan pembelajaran IPA terintegrasi dengan SCL diperoleh hasil bahwa SCL menunjukkan $77,78 \%$ yang berarti tingkat keterlaksanaan SCL termasuk dalam kategori tinggi. Rincian keterlaksanaan tiap aspek indikator SCL dapat dilihat pada Tabel 2. Di dalam pembelajaran SCL sudah mulai mengenalkan peserta didik dengan kegiatan percobaan, demonstrasi, presentasi, diskusi kelompok dan kegiatan di luar kelas. Peneliti memanfaatkan kebun sekolah dan bank sampah yang sudah terdapat di sekolah sebagai media penunjang mengingat masih berkaitan dengan materi yang dibelajarkan.

Tabel 2.

Keterlaksanaan Student Centered Learning

\begin{tabular}{|c|c|c|}
\hline Aspek SCL & Indikator & Keterlaksanaan \\
\hline \multirow{6}{*}{$\begin{array}{l}\text { Dinamika } \\
\text { kegiatan belajar } \\
\text { mengajar }\end{array}$} & Fokus kegiatan pembelajaran terletak pada siswa (guru sebagai fasilitator) & $6,67 \%$ \\
\hline & Guru menyajikan pembelajaran yang aktif dan integratif & $6,67 \%$ \\
\hline & Siswa berpartisipasi dalam diskusi (diskusi klasikal/diskusi kelompok) & $6,67 \%$ \\
\hline & Siswa mampu bekerja sama dalam kelompok & $4,44 \%$ \\
\hline & Siswa diberi kesempatan untuk mencari sumber belajar lain yang relevan & $4,44 \%$ \\
\hline & $\begin{array}{l}\text { Siswa mampu mengaplikasikan pengetahuan yang diperoleh dalam hidup } \\
\text { sehari-hari }\end{array}$ & $4,44 \%$ \\
\hline \multirow{4}{*}{$\begin{array}{l}\text { Metode } \\
\text { pembelajaran }\end{array}$} & Siswa diajak melakukan kegiatan pembelajaran di luar kelas & $6,67 \%$ \\
\hline & Guru memakai metode ceramah dalam kegiatan pembelajaran & $0,00 \%$ \\
\hline & Pembelajaran dilaksanakan dengan variasi metode atau teknik & $6,67 \%$ \\
\hline & Guru melaksanakan pembelajaran secara integratif & $4,44 \%$ \\
\hline \multirow{2}{*}{$\begin{array}{c}\text { Media } \\
\text { Pembelajaran }\end{array}$} & Guru menggunakan media yang bervariasi & $4,44 \%$ \\
\hline & Media membantu siswa memahami materi pembelajaran & $4,44 \%$ \\
\hline \multirow{3}{*}{$\begin{array}{l}\text { Penilaian } \\
\text { Pembelajaran }\end{array}$} & Guru melakukan penilaian pembelajaran yang variatif & $4,44 \%$ \\
\hline & Siswa memberikan umpan balik kepada guru & $6,67 \%$ \\
\hline & Siswa melakukan refleksi pribadi pada akhir pembelajaran & $6,67 \%$ \\
\hline & Total & $77,78 \%$ \\
\hline
\end{tabular}

Secara lebih mendalam, pembelajaran IPA terintegrasi disajikan sebagai berikut: 


\section{Minggu I}

Kegiatan diawali dengan penjelasan tema dan tujuan pembelajaran. Peneliti dan pendidik saling berkolaborasi mengkondisikan kelas supaya efektif. Di kegiatan awal dilakukan pembagian kelompok untuk mempersiapkan diskusi kelompok yang akan dilaksanakan pada minggu kedua dan ketiga. Dilakukan penjelasan mengenai apa yang harus peserta didik siapkan supaya diskusi dapat berjalan baik. Kemudian, peserta didik mempersiapkan diskusi secara berkelompok. Kegiatan ini memperbolehkan peserta didik untuk mencari informasi dari berbagai media.

\section{Minggu II}

Di minggu kedua pembelajaran terintegrasi diawali dengan melakukan brainstroming dan apersepi dengan mengajak peserta didik menyanyi "Alam Rindang". Dari lagu tersebut, peserta didik diajak mendiskusikan sejumlah pertanyaan yang sudah dicantumkan dalam buku panduan belajar. Secara berpasangan peserta didik mendiskusikan sejumlah pertanyaan di bawah pengawasan pendidik dan peneliti. Setelah diskusi mengenai materi selesai dilakukan refleksi awal terkait lagu dan materi. Peserta didik menuliskan refleksi dibimbing peneliti dan pendidik. Hasil refleksi menunjukkan bahwa sebagian peserta didik belum mampu mengkaitkan IPA dengan tindakan nyata sebagai perwujudan nilai iman budi pekerti. Kegiatan dilanjutkan dengan mengamati biji kacang merah. Peserta didik mengamati menggunakan panca indera mereka. Hasil pengamatan dituliskan dalam buku panduan belajar. Setelah selesai, dilanjutkan dengan menanam biji kacang merah tersebut dengan media kapas dan air. Peserta didik mengamati pertumbuhan dan perkembangan biji kacang tanah mereka selama satu minggu. Kegiatan ini diharap bisa mengenalkan peserta didik akan kedisiplinan, kemandirian, kejujuran dan keterampilan mengkomunikasikan hasil pengamatan baik lisan dan non lisan.

Materi biji dan buah dipelajari lebih dalam dari kegiatan mengamati dan diskusi kelompok. Peserta didik melakukan presentasi sesuai dengan pembagian kelompoknya. Pendalaman materi dilakukan dengan bantuan buku panduan belajar. Materi batang diawali dengan peserta didik melakuan percobaan dengan media sawi dan air bewarna. Percobaan dilakukan secara berpasangan. Peserta didik dibimbing untuk melakukan percobaan dan mengamati hingga terjadi perubahan warna. Pendidik dan peneliti membawa berbagai macam batang untuk melakukan demonstrasi di kelas. Penjelasan di awali oleh kelompok yang bertugas mempresentasikan batang kemudian dilanjutkan pemaparan dari pendidik guna mengkroscek informasi.

Akar yang merupakan salah satu bagian tumbuhan dipelajari peserta didik melalui kegiatan observasi di kebun sekolah. Peserta didik mencari dan mengamati sejumlah tumbuhan di kebun sekolah dan menganti akar tumbuhan tersebut. Peserta didik mengomunikasikan hasil secara non lisan di buku panduan belajar. Aktivitas ini dibarengi dengan pengamatan daun.

\section{Minggu III}

Minggu ketiga diawali dengan pemaparan hasil percobaan menanam biji kacang tanah dan dilanjutkan percobaan sawi dengan air berwarna. Kemudian kelompok akar, batang dan daun memimpin diskusi melalui presentasi. Pendidik dan peneliti saling berkolaborasi mengondisikan kelas. Kegiatan dilanjutkan 
dengan mengamati beberapa bunga yang dibawa kelompok, dilanjutkan dengan observasi bunga di kebun sekolah. Hasil observasi dikomunikasikan melalui buku panduan belajar. Sawi yang sudah tidak terpakai dari percobaan peserta didik dikumpulkan kemudian dibawa ke bank sampah untuk diproses menjadi pupuk kompos. Pembuatan kompos ini dibimbing oleh pengelola dan diawasi pendidik. Peserta didik melihat proses pembuatan kompos dari tanaman sekitar sekolah.

Di akhir kegiatan dilakukan refleksi baik refleksi materi dan keterkaitannya dengan nilai iman budi pekerti. Refleksi materi disajikan bersamaan dengan refleksi nilai iman budi pekerti yang berupa lembar pertanyaan. Hasil refleksi materi menunjukkan bahwa $83,72 \%$ berada di atas nilai 75 . Artinya peserta didik memahami materi "aku dan tumbuhan" dalam kategori tinggi. Hasil refleksi nilai iman budi pekerti peserta didik akan dibahas menurut pertanyaannya.

\section{Pertanyaan 1}

Saat kamu menanam biji kacang merah dan mengamatinya setiap hari, didapatkan biji yang semakin hari semakin tumbuh. Proses alami karya Tuhan berawal dari bagian putih pada biji, yang panjangnya \pm $1 \mathrm{~mm}$ tumbuh dan berkembang menjadi tanaman kacang merah yang bisa mencapai $20 \mathrm{~cm}$. Bagaimana pendapatmu tentang peristiwa ini?

Peneliti membagi ke dalam lima aspek untuk mempermudah menganalisis hasil refleksinya. Peneliti membagi dalam beberapa aspek dengan urutan dari tertinggi sampai terendah berturut-turut out of topics, baik dan senang, mengetahui manfaat, memahami progress dan sikap diri seperti yang tercantum pada Gambar 2 . Hasil refleksi peserta didik menunjukkan bahwa 37,2\% dari 86 peserta didik mengakui senang akan pembelajaran yang sudah dilaksanakan. $26,7 \%$ peserta didik masih menjawab refleksi dengan jawaban yang di luar topik. Jawaban di luar topik disini misalnya peserta didik mengurutkan bagaimana mereka menanam kacang tanah. 15,1\% mampu menuliskan refleksi dalam bentuk sikap diri seperti merawat tumbuhan dan lebih mensyukuri tumbuhan. $15,1 \%$ lainnya mampu memahami bahwa tumbuhan bisa menghasilkan tumbuhan dewasa karena adanya peristiwa atau progres. 5,8\% peserta didik mengetahui manfaat penting tumbuhan.

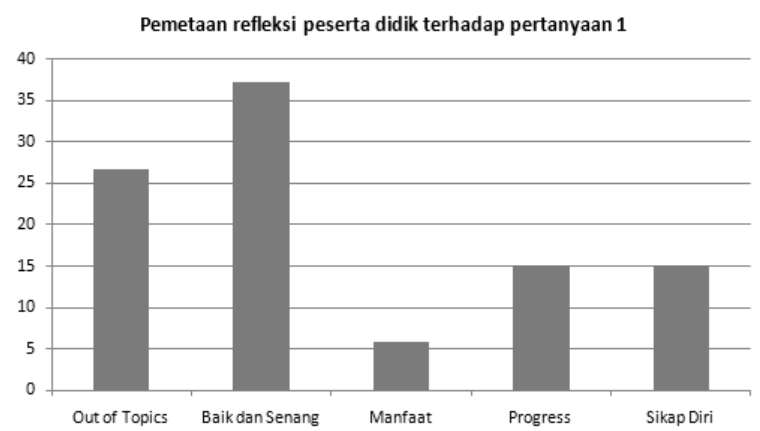

Gambar 2. Hasil pemetaan refleksi peserta didik terhadap pertanyaan 1

\section{Pertanyaan 2}

Tumbuh-tumbuhan menghasilkan oksigen. Oksigen ini kita perlukan untuk bernafas. Kita menghirup oksigen yang dihasilkan tumbuhan secara gratis. Tuliskan bagaimana caramu mensyukuri berkat Tuhan yang berupa oksigen gratis dan tumbuh-tumbuhan?

Peneliti membagi ke dalam empat aspek untuk mempermudah menganalisis hasil refleksinya. Peneliti membagi dalam beberapa aspek seperti yang tercantum pada Gambar 3. 
Pemetaan refleksi peserta didik terhadap pertanyaan 2

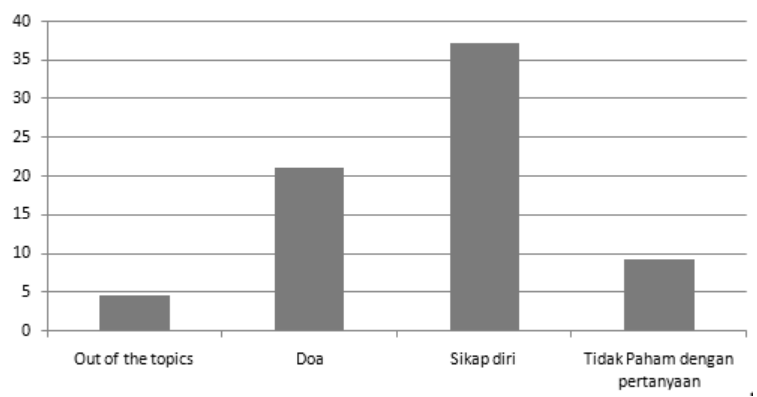

Gambar 3. Hasil pemetaan refleksi peserta didik terhadap pertanyaan 2

Berdasarkan Gambar 3, 63,9\% peserta didik mampu menunjukkan sikap diri dari pernyataan 2. Sikap diri yang muncul antara lain merawat dan memberi gambaran lebih luas (reboisasi, penanaman kembali dan semacamnya). $21,2 \%$ peserta didik mengungkapkan cara bersyukur dengan berdoa, 9,3\% peserta didik tidak paham dengan pertanyaan dan $4,6 \%$ peserta didik menjawab di luar topik, misalnya bersyukur.

Pertanyaan 3

Kita belajar mengenai jenis-jenis bentuk daun. Ada yang menjari, menyirip, melengkung dan sejajar. Daun saja memiliki keanekaragaman dan fungsinya masing-masing sesuai dengan bentuknya. Kita manusia yang diciptakan Tuhan juga memiliki banyak keanekaragaman, contohnya ada yang berambut lurus atau keriting, ada yang berkulit putih atau coklat. Menurutmu bagaimana sikapmu terhadap keanekaragaman kita (manusia)? Peneliti membagi ke dalam empat aspek untuk mempermudah menganalisis hasil refleksinya. Peneliti membagi dalam beberapa aspek seperti yang ditunjukkan Gambar 4.

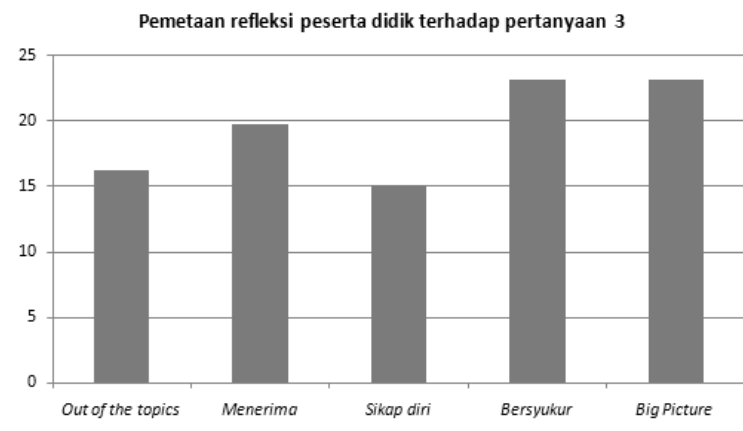

Gambar 4. Hasil pemetaan refleksi peserta didik terhadap pertanyaan 3

Berdasarkan Gambar 4, 23,2\% peserta didik menuliskan big picture bahwa sikap yang bisa dilakukan adalah tidak mengolok-olok, tidak berteman dengan memilih agama, melihat keanekaragaman merupakan hal yang unik, saling bantu membantu dan mengembangkan perbedaan. 23,2\% lainnya menuliskan sikap bersyukur menghargai, $15,1 \%$ bersikap dengan berteman, 19,8\% dengan menerima apa adanya dan $16,3 \%$ menjawab di luar topik permasalahan (memelihara tanaman, daun menyirip melengkung).

\section{Pertanyaan 4}

Apakah kamu sudah berusaha menjaga lingkungan hidup di sekolah, di rumah dan di tempat umum? Jika sudah, uraikan apa yang sudah kamu lakukan beserta alasannya. Jika belum, tuliskan alasan mengapa kamu belum melakukannya.

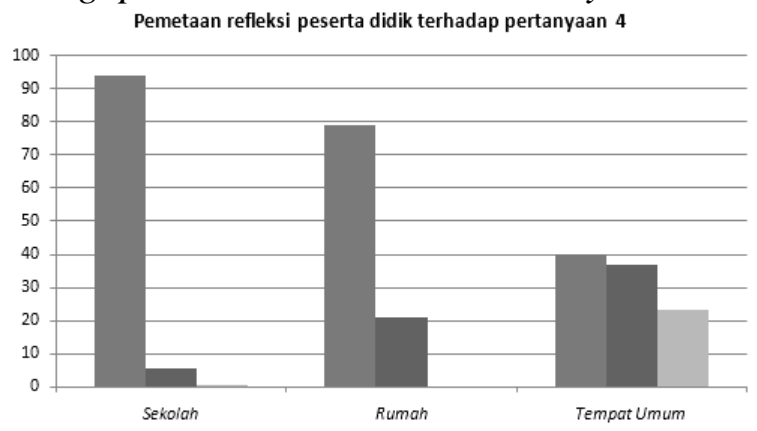

Gambar 5. Hasil pemetaan refleksi peserta didik terhadap pertanyaan 4

Gambar 5 menunjukkan bahwa

94\% peserta didik melakukannya di 
sekolah, 79\% sudah melakukannya di rumah dan $40 \%$ peserta didik juga melakukannya di tempat umum. Kegiatan menjadi lingkungan hidup di sekolah yang peserta didik lakukan antara lain menyiram dan menyukai tanaman, tidak membuang sampah sembarangan, mau menjaga tanaman karena piket kelas, peserta didik tahu manfaat oksigen yang dihasilkan tanaman. 5,6\% yang belum melaksanakan di sekolah dikarenakan malas dan asik bermain. Kegiatan menjadi lingkungan hidup di rumah yang peserta didik lakukan antara lain membantu orangtua menanam dan merawat, suka tanaman, menyiram, membuang sampah, mengetahui manfaat tanaman, tidak membuang kertas karena kertas terbuat dari pohon. 20,9\% yang belum melakukan di rumah dikarenakan tidak ada waktu, tidak tahu, tidak ada tanaman di rumah dan malas.

Kegiatan menjaga lingkungan hidup di tempat umum yang peserta didik lakukan antara lain kerja bakti, tidak menginjak rumput, hemat air, buang sampah pada tempatnya, mencegah polusi udara dan air. 36,7\% belum melakukan karena berbagai alasan yakni malas, merasa jorok dan kotor, tidak diperbolehkan orang tua dan masih membuang sampah sembarangan.

Pertanyaan 5

Apakah kamu menyadari bahwa kamu dan lingkungan hidup di sekitarmu adalah sama-sama makhluk hidup? Bagaimana cara kamu memelihara lingkungan di sekitarmu?

Gambar 6 menunjukkan 38,3\% peserta didik mampu menggambarkan sikap dalam big pictures misalnya saling bergotong royong membersihkan lingkungan, menanam lebih banyak tanaman, tidak merusak lingkungan, tidak menyakiti hewan, tidak mencorat-coret fasilitas umum, menyadari bahwa tumbuhan merupakan sumber kehidupan, dan reboisasi. 36\% menyikapi dengan menyiram dan memupuk tanaman, 21,3\% membuang sampah di tempatnya, 3,3\% belum menyadari dan $1,1 \%$ menyikapi dengan tidak memetik bunga buah.

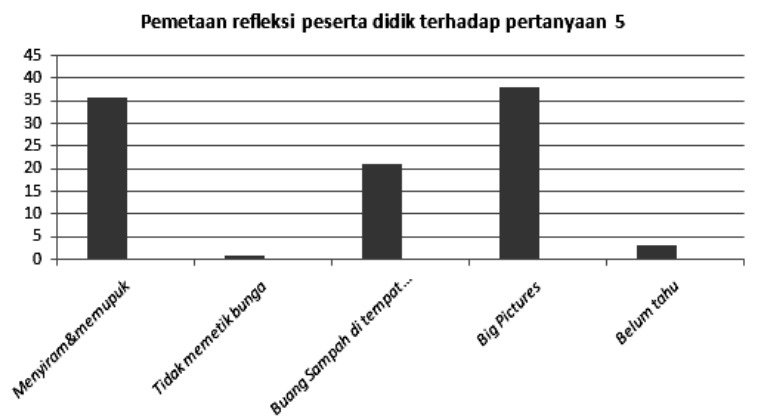

Gambar 6. Hasil pemetaan refleksi peserta didik terhadap pertanyaan 5

\section{SIMPULAN DAN SARAN}

\section{Simpulan}

Berdasarkan tujuan serta hasil penelitian dapat disimpulkan bahwa:

1) Pembelajaran IPA terintegrasi nilai iman budi pekeri dapat diimplemantasikan di sekolah dasar kelas IV. Hasil implementasi menunjukkan bahwa pembelajaran SCL terintegrasi berada dalam kategori tinggi dengan nilai $77,78 \%$ meningkat $33,33 \%$ dari kegiatan pembelajaran awal.

2) Hasil refleksi materi peserta didik menunjukkan $83,72 \%$ peserta didik berada di atas kriteria ketuntasan minimal. Pembelajaran IPA terintegrasi juga mampu mengantarkan peserta didik untuk merefleksi nilai iman budi pekerti dengan baik. Hal ini terlihat dari setiap jawaban yang dituliskan memuat sikap diri, mengetahui progres pengalaman, manfaat dan rasa syukur kepada Tuhan dengan berbagai sikap. 


\section{Saran}

Saran bagi penelitian selanjutnya yaitu mengenai pengembangan rencana pelaksanaan pembelajaran secara lebih luas dan mengikutsertakan nilai-nilai keimanan. Panduan menyusun pembelajaran terintegratif juga perlu ditindaklanjuti. Pemahaman tematik belum optimal dipahami sehingga di dalam pelaksanaan pembelajaran masih ditemui berbagai kendala.

\section{DAFTAR PUSTAKA}

Akpınar, E., Yıldız, E., Tatar, N., \& Ergin, Ö. (2009). Students attitudes toward science and technology: An investigation of gender, grade level, and academic achievement. Procedia - Social and Behavioral Sciences, 1(1), 2804-2808. Dipetik dari https://www.researchgate.net/publica tion/240448201_Students\%27_attitu des toward_science_and technology _An_investigation_of_gender_grade level_and_academic_achievement pada tanggal 15 Agustus 2017.

Antika, R. R. (2014). Proses Pembelajaran Berbasis Student Centered Learning (Studi Deskriptif di Sekolah Menengah Pertama Islam Baitul 'Izzah, Nganjuk). Biokultur, Vol. III/No.1/Januari-Juni 2014 , 251.

Attard, A., \& all, e. (2010). Student Centred Learning, Toolkit for students Staffs, and Higher Education Institution. Brussel: Education International and the European Student Union.

Creswell, J.W., (2003). Research Design: Qualitative, Quantitative, and Mixed Method Approaches, USA: Sage Publications.

Fowler, J. W., (1981). Stages Of Faith, The Psychology of Human Development and the Quest for Meaning, San Franscisco: Harper and Row.

Jelen, T. G., \& Lockett, L. A. (2014). Religion, partisanship, and attitudes toward science policy. SAGE Open, 4(1). Diakses dari http://journals.sagepub.com/doi/abs/ $\underline{10.1177 / 2158244013518932}$ pada tanggal 15 Agustus 2017.

Nasution, S., (1986). Asas-Asas Kurikulum. Bandung: Jemmars.

Salirawati, D. (2011). Pendidikan Karakter Terintegrasi dalam Mata Pelajaran. Yogyakarta.

Suwarjo, Maryatun, I., \& Kusumadewi, N. (2012). Penerapan Student Centered Approach pad Pembelajaran Taman Kanak-Kanak Kelompok B (Studi Kasus di Sekolah Laboratorium Rumah Citta). Jurnal Pendidikan Anak Volume 1 Edisi 1, 79-102.

Trilling, B., \& Fadel, C. (2009). 21th Century Skills: Learning for Life in Our Times. San Fransisco: JosseyBass.

UNESCO. (t.thn.). The four pillars of learning. Dipetik Februari 08, 2017, dari http://www.unesco.org/new/en/ education/networks/global-networks /aspnet/about-us/strategy/the-fourpillars-of-learning/. Diakses tanggal 28 Mei 2017)

\section{PROFIL SINGKAT}

Naomi Dias Laksita Dewi, M.Pd memperoleh gelar sarjana dan magister di Program Studi Pendidikan Sains Universitas Negeri Yogyakarta. Lulus dan berhasil memperoleh gelas magister pendidikannya pada tahun 2015. Kini aktif mengajar di Program Studi Pendidikan Guru Sekolah Dasar Unika Atma Jaya Jakarta. 